\title{
JAK ZOSTALAM ASYSTENTKĄ I NIECO O SKUTKACH TEGO WYDARZENIA
}

\section{Stanisława Bartosiewicz}

Doktor honoris causa Uniwersytetu Ekonomicznego we Wrocławiu Uniwersytet Ekonomiczny we Wrocławiu, Polska e-mail: stanislawa.bartosiewicz@gmail.com

(C) 2020 Stanisława Bartosiewicz

This work is licensed under the Creative Commons Attribution-ShareAlike 4.0 International License. To view a copy of this license, visit http://creativecommons.org/licenses/by-sa/4.0/

Quote as: Bartosiewicz, S. (2020). Jak zostałam asystentką i nieco o skutkach tego wydarzenia. Śląski Przegląd Statystyczny, 18(24).

DOI: $10.15611 /$ sps.2020.18.01

JEL Classification: A29

$$
\begin{array}{r}
\text { Byt rok 1946, dnia } 5 \text { kwietnia. } \\
\text { Stoję z rodzicami na dworcu we Lwowie, } \\
\text { czekając na dostawienie towarowych wagonów, } \\
\text { wywożacych nas w nieznane, na Zachód. } \\
\text { Jest piękny stoneczny dzień. Pamiętam, że nucitam piosenkę: } \\
\text { „(...) Może uda się, że powrócę zdrów } \\
\text { I zobaczę miasto Lwów”. }
\end{array}
$$

Pociąg szerokim torami wywozi nas do Rawy Ruskiej, gdzie musimy się przesiąść do towarowego wagonu na torach europejskich. Po kilkunastu dniach dojeżdżamy do stacji o nazwie Wrześniów, przy miejscowości Puszczyków-Zdrój. W owym czasie były takie obyczaje, że dworcom nadawały nazwy władze kolejowe, a miejscowościom - władze samorządowe. Wymieniona przeze mnie miejscowość była już na Ziemiach Odzyskanych. Obecnie nazywa się Polanica-Zdrój. Pamiętam jeszcze jedną miejscowość na Dolnym Śląsku, która miała taką samą przypadłość, jak powyżej wymieniona. To Dzierżoniów, który nazywał się wówczas Rychbach, natomiast stacja kolejowa Drobniszów. W Puszczykowie-Zdroju pobyliśmy tydzień lub trochę więcej i przenieśliśmy się do Żarowa koło Świdnicy, gdzie oboje z ojcem podjęliśmy się próby wyprostowania rachunków w spółdzielni Samopomoc Chłopska, którą to instytucją władał klan Gruszków. Jedna młoda panna Gruszkówna nie wiedziała, co oznaczają słowa „winien” oraz „ma”. Mój ojciec został głównym księgowym, 
chociaż przed wojną był kapitanem w wojsku, ale jako inwalida I wojNr 18(24) ny światowej (ranny jako żołnierz legionów Piłsudskiego - utracił mniej więcej połowę jednej stopy) na potrzeby pułku prowadził coś w rodzaju rachunkowości.

Ja zaś w ostatnim roku przedwojennym ukończyłam I rok studiów na Akademii Handlu Zagranicznego we Lwowie i jeszcze cokolwiek z tamtych wiadomości pamiętałam.

Nie zasiedzieliśmy się długo w Żarowie. Pierwszy wyemigrował do Wrocławia mój ojciec - w poszukiwaniu mieszkania i pracy dla siebie oraz rodziny. Ja objęłam po nim stanowisko głównej księgowej, bardzo uciążliwe ze względu na ciągłą walkę z rządzącym w spółdzielni klanem.

Tymczasem we Wrocławiu rozniosła się wiadomość o tym, że zostaje powołana do życia nowa uczelnia - Wyższa Szkoła Handlowa (WSH), jako własność Towarzystwa Popierania Nauk Ekonomiczno-Handlowych. Rekrutacja studentów rozpoczęła się w styczniu 1947 roku, tylko w formie zapisów, bez egzaminów wstępnych. Ponieważ miałam już ukończony I rok studiów we Lwowie, zostałam przyjęta na II rok, z uzupełnieniem trzech egzaminów.

WSH była uczelnią prywatną, płaciło się czesne, które nie było duże, gdyż moje wynagrodzenie wystarczało na opłacenie nauki i utrzymanie się.

W 1950 roku uczelnia straciła status uczelni prywatnej i nastąpiło przekształcenie w uczelnię publiczną - Wyższą Szkołę Ekonomiczną (z dwoma Wydziałami: Przemysłu i Finansów) ${ }^{1}$, oraz zwiększono liczbę lat nauki do 4, zmieniając również program studiów. Uczelnia otrzymała prawo nadawania stopnia magistra ekonomii.

W pierwszych latach powojennych uczelnia była w sytuacji trudnej. Nie miała siedziby ani ustalonej kadry naukowej. Z pomocą przyszedł nam Uniwersytet Wrocławski, który już funkcjonował (od 1945 r.), a zwłaszcza Wydział Prawa przy ulicy Uniwersyteckiej (wówczas była to ulica Uniwersytetów Szwedzkich²).

Od Uniwersytetu otrzymaliśmy do dyspozycji część pomieszczeń dla administracji oraz pokoje dla profesorów i ich podopiecznych. Pomieszczenia te nie znajdowały się w gmachu głównym, lecz po drugiej stronie ulicy. W gmachu głównym Uniwersytetu mieliśmy do dyspozycji bardzo dużą salę wykładową - salę im. Oswalda Balzera. Ze względu na dużą liczbę studentów potrzebne były odpowiednie sale wykładowe (już

\footnotetext{
${ }^{1}$ Następnie w 1974 roku w miejsce WSE powstała Akademia Ekonomiczna im. Oskara Langego, a w 2008 roku nastąpiła zmiana nazwy uczelni na Uniwersytet Ekonomiczny we Wrocławiu. Więcej szczegółów o początkach działalności Wyższej Szkoły Handlowej (i następnie Wyższej Szkoły Ekonomicznej w książce pt. Księga 60-lecia Akademii Ekonomicznej im. Oskara Langego we Wroctawiu (Chumiński, 2007).
}

${ }^{2}$ Do 1948 roku nazywała się ulicą Urszulanek. 
w 1947 roku na I rok studiów zapisało się 1589 osób (na II rok zapisało się 950 osób, na III zaś - 557 osób). Od 1949 roku WSH miała do dyspozycji własny budynek przy ul. Tęczowej.

Zapewne wśród zapisanych studentów przedział wiekowy był bardzo duży. Ja miałam 26 lat, ale byli na studiach zarówno starsi ode mnie, jak i młodsi. Przypuszczalnie, byli tacy, którzy w czasie wojny ze zrozumiałych względów musieli zmieniać swoją tożsamość. Wobec tego przedłożone świadectwa ich wykształcenia mogły mieć zrozumiały „grzech” braku prawdy. Prawdopodobnie byli i tacy, którzy w ogóle nie mieli matury. Również stan wiedzy wielu zapisanych studentów nie był na tyle wystarczający, aby zrozumieć wykład ze statystyki czy księgowości (wszak nie było egzaminów wstępnych). W porównaniu $\mathrm{z}$ wymienioną liczbą studentów liczba wydanych dyplomów ukończenia studiów nie była dużym ułamkiem³.

Kadrę uczelni stanowili m.in. profesorowie z Wydziału Prawno-Administracyjnego Uniwersytetu Wrocławskiego (zwłaszcza dawni pracownicy Akademii Handlu Zagranicznego we Lwowie lub Uniwersytetu Jana Kazimierza we Lwowie czy Uniwersytetu Stefana Batorego w Wilnie), którzy mieli odpowiednie dokumenty świadczące o nadanym tytule profesora, ale też inni, w tym też tacy, którzy nie mieli żadnych odpowiednich dokumentów. Jednym z tych ostatnich był Jan Falewicz - mój niezapomniany mistrz, Profesor przez duże „P”. Profesor Jan Falewicz był zaledwie magistrem inżynierem Politechniki Petersburskiej, którą ukończył w 1917 roku, uzyskując dyplom inżyniera komunikacji, specjalność - budowa mostów. O Politechnice Petersburskiej mówiono żartobliwie, iż nie uczono tam tylko ginekologii. Nauczyła natomiast Jana Falewicza „nie bać się podchodzić z narzędziem matematycznej analizy do najrozmaitszych zjawisk i stosować je przy rozwiązywaniu praktycznych zagadnień wszędzie, gdzie nadarzają się po temu odpowiednie warunki” (Bartosiewicz, 2012).

W okresie międzywojennym Profesor pracował w Katowicach na stanowiskach kierowniczych w dużych przedsiębiorstwach przemysłowych w śląskim przemyśle górniczym i hutniczym. Nauczał także elementów statystyki pomocnej w zarządzaniu przedsiębiorstwem na Wyższym Studium Nauk Społeczno-Gospodarczych w Katowicach. Zainteresowania badawcze Profesora można ująć w 3 słowach: rentowność, gospodarność, koszty. Jest autorem książki o tytule obejmującym te słowa: Rentowność, gospodarność, koszty. Przyczynek do teorii mikroekonometrii, w której przedstawił metodykę badania wymienionych zagadnień przy wykorzystaniu metod statystycznych, a zwłaszcza analizy regresji i korelacji.

${ }^{3}$ Spośród 1589 osób, które zapisały się na I rok, przeszło 40\% nie ukończyło tego roku (por. Chumiński, 2007). 
W książce tej Jan Falewicz na podstawie własnych badań empirycznych, Nr 18(24) współpracując z przemysłem, przedstawił także konkretne sposoby wdrożenia zaproponowanych metod statystycznych do praktyki gospodarczej.

W 1947 roku Jan Falewicz został przyjęty do kadry naukowej WSH. W 1950 roku został zatrudniony na stanowisku zastępcy profesora (po przekształceniu uczelni w państwową zawodową WSE) i następnie powierzono mu Katedrę Statystyki na Wydziale Planowania Przemysłu).

Po 7 latach uzyskał tytuł docenta, po złożeniu pracy kandydackiej pt. „Kontrola niezmienności związku korelacyjnego”. W późniejszych latach próbował zrobić doktorat, niestety nie zdążył. W 1960 roku odszedł z pracy na WSE i przeszedł na rentę specjalną ${ }^{4}$ (por. Ostasiewicz, 2000).

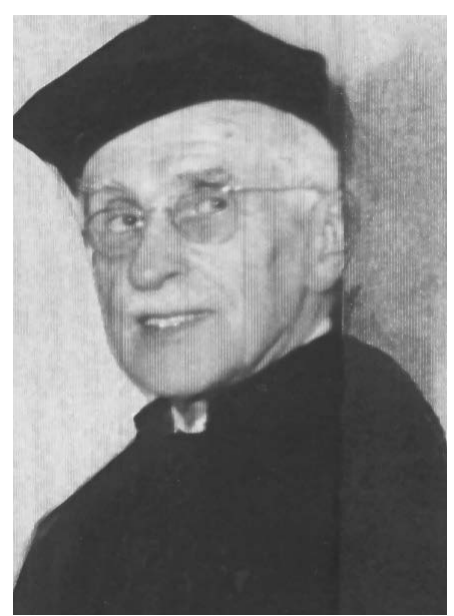

Profesor Jan Falewicz w todze

Pracując na uczelni, prowadził zajęcia dydaktyczne m.in. ze statystyki, elementów wyższej matematyki, organizacji i ekonomiki przedsiębiorstw przemysłowych (w tym modeli kosztów). Należy dodać, że jego wykłady ze statystyki nie ograniczały się tylko do statystyki opisowej, lecz wprowadzał dodatkowo elementy rachunku prawdopodobieństwa i statystyki matematycznej.

Mając w pamięci te wykłady oraz wiele opracowań naukowych, uważam, że Profesor Falewicz był prekursorem dzisiejszej ekonometrii.

Wszyscy jego podopieczni zwracali się zawsze do niego „Panie Profesorze”, bo był to profesor prawdziwy, nie potrzebował żadnych papierów, żeby to udowodnić. Swoją kadrę pomocników tworzył w ten sposób, że uczył nas nie tylko statystyki, ale też przekazywał nam naukowe ciekawostki. Profesor inicjował też dyskusje na tematy społeczne, właściwie wtedy niemodne z racji naszej zależności od Związku Radzieckiego.

Na rysunku 1 przedstawiono drzewo genealogiczne (mojej koncepcji graficznej) - Profesor Jan Falewicz i jego ,naukowe dzieci”. Profesor Falewicz stanowi pień główny, gdyż, jak wspomniałam wcześniej, można go uważać za twórcę ekonometrii wrocławskiej.

\footnotetext{
${ }^{4}$ Więcej o historii Katedry Statystyki Czytelnik może dowiedzieć się w pracy pt. Katedra Statystyki Akademii Ekonomicznej we Wrocławiu 1950-2000 (Ostasiewicz, 2000).
} 


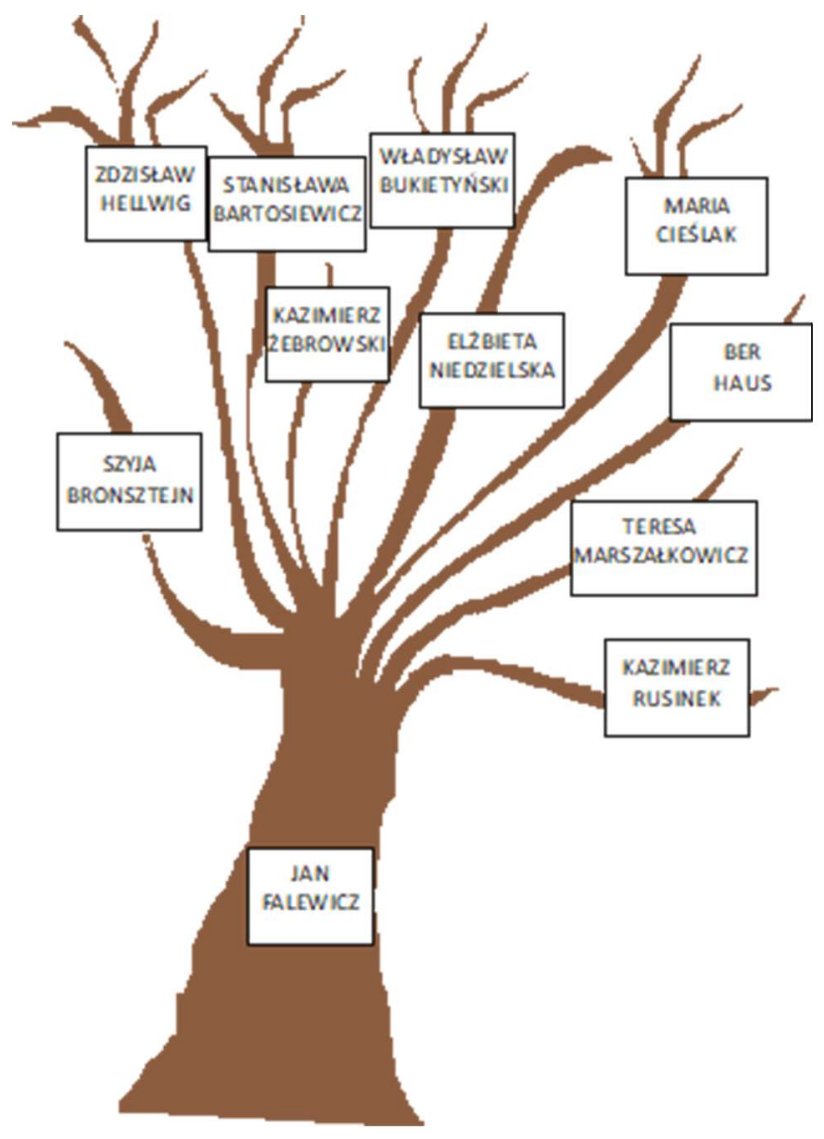

Rys. 1. Profesor Jan Falewicz i jego „naukowe dzieci” (por. Bartosiewicz, 2007, s. 8)

Powrócę jeszcze do pierwszych zajęć dydaktycznych na Wyższej Szkole Handlowej. Odbywały się one po południu, głównie były to tylko wykłady (ćwiczenia były jedynie z języków). Najbardziej podobał mi przedmiot „organizacja i ekonomika przedsiębiorstw”, do którego wykład prowadził Profesor Falewicz. Ten przedmiot uczył nas wykorzystywania statystyki do zagadnień wymienionych w nazwie przedmiotu, szczególnie ekonometrycznej analizy kosztów.

Ja pracowałam wówczas w bursie inwalidów wojennych i byłam jedyną osobą, która zajmowała się sprawami administracyjnymi. W pracy pisałam na maszynie coś w rodzaju referatów z wykładów Profesora (na czerwonej taśmie, żeby oszczędzać czarną na urzędowe pisma). Czasami dorysowywałam do treści odpowiednie rysunki. Każdy wykład Profesora Falewicza był potem takim referacikiem, który można byłoby wygłosić na jakieś małej konferencji. 
ŚLĄSKI

PRZEGLĄD STATYSTYCZNY

Nr 18(24)

Któregoś dnia Profesor poprosił studentów o notatki z wykładu. Otrzymał tylko od dwóch osób: ode mnie oraz od Ani Leszczyńskiej (która miała w zeszycie prawdziwe notatki). Profesor jeszcze tego samego dnia zaproponował mi tzw. wolontariat - pracę asystentki w Katedrze Ekonomii Przedsiębiorstwa (bez wynagrodzenia). Jest przysłowie: co drugi głupi ma szczęście. Ja miałam szczęście, że miałam takiego mistrza. Do dzisiaj uważam Profesora za swojego mistrza i do zdjęcia, które mam na stoliku, codziennie mówię „Dzień dobry Panie Profesorze!”

$\mathrm{Na}$ początku nie miałam ważnych zadań jako asystentka. Profesor uczył nas i przekazywał nam swoją wiedzę naukową. Pamiętam, że raz, zastępując Profesora, przygotowywałam wykład na temat tworzenia różnych wykresów w statystyce. Miałam wtedy ogromną tremę, stojąc przed liczną grupą studentów w ogromnej sali wykładowej (była to sala Balzera w gmachu głównym Uniwersytetu Wrocławskiego).

Innym, samodzielnym zadaniem, które otrzymałam od Profesora, było napisanie recenzji pracy doktorskiej, autorstwa jednej z pracownic Katedry Ekonomii Politycznej.

Asystentką etatową byłam w latach 1948-1950, będąc jednocześnie studentką na tej samej uczelni. Zdarzało się, że prowadziłam w semestrze 7 różnych wykładów - zastosowanie statystyki w różnych branżach. Wymagało to ode mnie przygotowywania różnych przykładów praktycznych do każdego z tych wykładów.

W okresie, gdy już zaczęłam pracę asystentki, Profesor Falewicz dostał zlecenie od Pafawagu, do zarządzania którego przybyli pracownicy dawnej fabryki wagonów Lilpop, Rau i Loewenstein, zniszczonej po powstaniu w Warszawie.

Było to zamówienie na opracowanie budżetu kosztów produkcji. Ja miałam opracować koszty działu produkcyjnego węglarkarni, z której co 27 minut wychodziła nowa węglarka. Była to moja pierwsza przygoda z przemysłem. Na jej podstawie przygotowałam pod kierunkiem prof. Jana Falewicza pracę dyplomową pt. Krytyka systemu Clarka (na zakończenie studiów I stopnia - w 1949 roku).

Jak się okazało, mam drugi numer dyplomu. Niestety nie wiem, kto był pierwszym absolwentem WSH.

$\mathrm{Z}$ moją pracą dyplomową wiążą się wspomnienia $\mathrm{z}$ pewnego zebrania wszystkich pracowników uczelni zwołanego w 1952 roku przez uczelnianą organizację partyjną, aby potępić poglądy społeczno-ekonomiczne Wincentego Stysia. Jeden z uczniów profesora Wincentego Stysia wygłosił tzw. oskarżycielski referat (sądzę, że referujący prawdopodobnie został zmuszony do przygotowania takiego wystąpienia). W tym referacie padło moje nazwisko. Mianowicie, przy omawianiu prac naukowych powstałych w środowisku WSH, pochwalono moją pracę dyplomową jako najlepszą 
spośród obronionych w tym okresie. Jednakże, zwrócono przy tym uwagę na nazbyt duże eksponowanie metod używanych w kapitalistycznych krajach. Przedmówca podkreślił, iż to wina promotora, a nie autorki pracy.

$\mathrm{Na}$ te zarzuty Profesor Falewicz powiedział mi: "Pani Stasiu, będę musiał płacić Pani alimenty".

Opracowanie kosztów działu produkcyjnego węglarkarni (które zawarłam w wymienionej pracy dyplomowej) było moją pierwszą pracą zaliczaną do tzw. półkowników.

Zlecenia dla uczelni na rzecz przemysłu wynikały z faktu funkcjonowania w każdym dużym przedsiębiorstwie odpowiedniej komórki do kontaktu z uczelniami, komórki, której zadaniem było opracowywanie procesów produkcyjnych.

Przy ich wykonywaniu Profesor pokazał nam piękno przemysłu. Widziałam w kopalni „Prezydent” (koło Katowic) wydobywanie węgla w prymitywny sposób, a także jak przygotowuje się tzw. podsadzkę (wypełnianie pustki powstałej na skutek eksploatacji węgla kamiennego), która miała zapobiegać szkodom górniczym na powierzchni. Profesor zawiózł nas też do huty Batory w Chorzowie, gdzie obserwowaliśmy spust surówki z wielkiego pieca oraz podziwialiśmy ciężką pracę hutników. znać;

Pracując przy kolejnych „,półkownikach”, miałam również okazję po-

- proces technologiczny produkcji cukru - w cukrowni na Klecinie (Wrocław),

- proces powstawania piwa - w Browarze Piastowskim we Wrocławiu,

- organizację taboru tramwajowego we Wrocławiu.

Z przygotowywaniem „półkowników” wiąże się następująca anegdota. Kiedyś dostaliśmy - jako zlecone z Polmosu - zadanie optymalizacji wymiaru magazynu na wyroby gotowe. Od jednego z pracowników z zakładu dostaliśmy niezbędne dane, a do obliczeń służyła nam wówczas maszyna cyfrowa ODRA1003. Profesor A. Smoluk uczył nas trochę programowania, niezbędnego do obsługi tej maszyny. Dwie panie wprowadzały program, korzystając z taśm dziurkowanych. Panie bardzo kochały swoją ODRĘ i czasami mówiły: „Ona tego nie lubi”. Program do obliczeń napisał prof. Smoluk, niestety ze względu na złożoność modelu, wielość ograniczeń, ODRA nie była w stanie tego policzyć. Skontaktowaliśmy się z pracownikiem z Polmosu, który pomógł nam dokonać redukcji niektórych warunków ograniczających. Profesor Smoluk poprawił program i zostawił mi go do wprowadzenia, po czym wyjechał na 2 tygodnie. Niestety, w programie był błąd i znów ODRA nie mogła wykonać obliczenia („Ona tego nie lubi!”). Znalazłam błąd w programie (to była pomyłka w znaku w jednym z działań), chociaż nie znałam się dobrze na programowaniu. 
ŚLASKI

PRZEGLĄD STATYSTYCZNY

Nr 18(24)

I jeszcze trochę o Profesorze Janie Falewiczu. Był on również promotorem mojej pracy magisterskiej pt. „Analiza korelacyjna narzędziem badania gospodarności przedsiębiorstw". Egzamin magisterski odbył się w lipcu 1953 r. Zostałam magistrem ekonomistą w zakresie statystyki.

I tu muszę przyznać się do zdrady uczelni. Otóż moją uczelnię zdradziłam na 4 lata - po zdaniu egzaminu magisterskiego wyjechałam do Warszawy do męża, aby spełnić obowiązek demograficzny i przysporzyć krajowi nowych obywateli. Po zrobieniu kursu dokumentalisty, pracując w Centralnym Instytucie Dokumentacji Naukowo-Technicznej, nabyłam umiejętność streszczania nowych pozycji naukowo-technicznych. Napisałam z 7 takich opisów. Dodatkowo, na podstawie wyników z ankiety, którą wysłałam do przedsiębiorstw, napisałam obszerne sprawozdanie oraz artykuł do „Przeglądu Technicznego”.

W 1957 roku wróciliśmy z dwojgiem dzieci do Wrocławia i oczywiście zatrudniłam się u Profesora Jana Falewicza. A w następnym roku Profesor powierzył mi przygotowanie się do nowego przedmiotu - ekonometrii. Byłam pierwszą prowadzącą ten przedmiot. Nie mając zbyt wiele literatury w tym zakresie, doświadczyłam blasków i cieni pracy dydaktycznej.

Poinformuję teraz Czytelników o moim największym sukcesie dydaktycznym oraz największej porażce.

Oto sukces. Kiedyś na naszej uczelni przez kilka lat była szkoła wieczorowa, na której studiowały osoby pracujące w różnych instytutach naukowych, nie mające ukończonych studiów

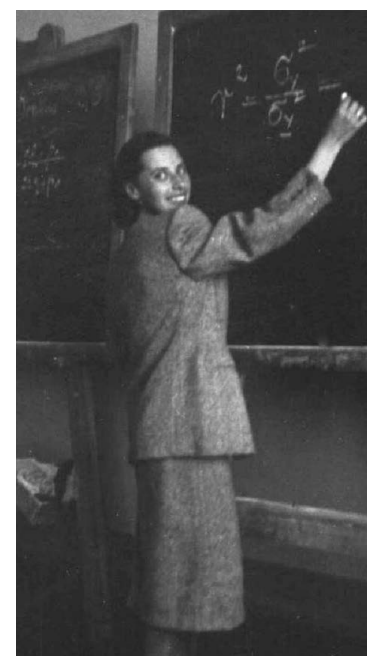

Wykładam wyższych. Na ogół byli to ludzie starsi. Ja prowadziłam dla nich wykład ze statystyki opisowej. Opowiadałam o szeregach czasowych na przykładzie różnych zjawisk ekonomicznych, demograficznych. Wykład był dobrze przygotowany. W pewnym momencie musiałam wziąć głęboki oddech i... zapadła cisza. Studentów było może z 60 osób. Nagle z jednej ławki odezwał się głos: „Boże, jakie to piękne!”

A oto klęska dydaktyczna. Mam wykład w budynku A, w sali amfiteatralnej zapełnionej do połowy, kilka osób pośrodku sali. W ostatniej ławce kilku panów, którzy coś tam robili. I znów, kiedy w pewnym momencie musiałam wziąć oddech, zapadła cisza... W tej ciszy rozległ się radosny okrzyk: „dwa piki!” Do dzisiaj żałuję, że nie powiedziałam „kontra!”.

Pod kierunkiem Jana Falewicza napisałam także rozprawę doktorską pt. „Adekwatność wskaźników charakteryzujących działalność przedsię- 
biorstw", której obrona odbyła się na początku 1962 roku. Od 1968 roku kierowałam Zakładem Ekonometrii i Katedrą Ekonometrii. Oprócz zajęć z ekonometrii prowadziłam również zajęcia dydaktyczne ze statystyki, STATYSTYCZNY metody reprezentacyjnej, programowania matematycznego, przepływów międzygałęziowych, wielowymiarowej analizy porównawczej.

Na podstawie notatek z prowadzonych wykładów napisałam podręcznik z ekonometrii, który cieszył się wówczas ogromnym popytem. Bardzo szybko został sprzedany i wydawnictwo poprosiło o przygotowanie drugiego wydania. Książka Ekonometria. Technologia ekonometrycznego przetwarzania informacji stała się też podstawą mojej rozprawy habilitacyjnej (por. Bartosiewicz, 1976, 1978, 1989). W roku 1984 uzyskałam stopień doktora habilitowanego nauk ekonomicznych, a cztery lata później otrzymałam tytuł naukowy profesora nadzwyczajnego nauk ekonomicznych. Na zwyczajnego już nie starczyło czasu

$\mathrm{Na}$ Uniwersytecie Ekonomicznym pracowałam do 1990 roku, kiedy to z mocy ustawy musiałam odejść na emeryturę. Jeszcze przez 5 lat miałam częściowy etat na uczelni, na której prowadziłam seminarium magisterskie. Niestety nasza uczelnia znalazła się w sytuacji szewca, który bez butów chodzi; miała długi z powodu nadmiernych inwestycji. Wobec tego - na wniosek rektora - podjęto kolejną uchwałę, która obejmowała odmowę zatrudniania profesorów emerytów. Ja już w tym okresie równocześnie pracowałam w Wyższej Szkole Bankowej. Najpierw byłam zatrudniona w Poznaniu, w wydziale zamiejscowym WSB we Wrocławiu, a potem już w Wyższej Szkole Bankowej we Wrocławiu, funkcjonującej samodzielnie.

Moja praca na WSB polegała na tym, że miałam seminaria licencjackie i magisterskie. I tak pracowałam do końca 2019 roku, kiedy dostałam „emeryturę bis".

Kiedy piszę te zdania o sobie, mam już ukończone 100 lat. Do 95. roku życia nie odczuwałam, że się starzeję, dopiero od tego roku pojawiły się problemy zdrowotne. Te różne dolegliwości zdrowotne sprawiły, że mam teraz dwa marzenia:

1) że zjawi się cudotwórca, który położy ręce na mojej głowie i powie: „masz widzieć!”,

2) a kiedy przyjdzie żegnać się ze światem, nastąpi ono w nieświadomości, bo kocham cię życie.

Życie pozwala uczestniczyć w procesie poznania, które dla mnie jest najważniejsze. 


\section{Literatura}

Bartosiewicz, S. (1976, 1978, 1989). Ekonometria. Technologia ekonometrycznego przetwarzania informacji. Wrocław: Akademia Ekonomiczna.

Bartosiewicz, S. (2006). Okruchy życia. Wrocław: Akademia Ekonomiczna.

Bartosiewicz, S. (2007). Ekonometria wrocławska. Wrocław: Akademia Ekonomiczna.

Bartosiewicz, S. (2012). Falewicz Jan (1890-1965). W: Statystycy Polscy. Warszawa: Główny Urząd Statystyczny, Polskie Towarzystwo Statystyczne.

Chumiński, J. (2007). Księga 60-lecia Akademii Ekonomicznej im. Oskara Langego we Wrocławiu. Wrocław.

Ostasiewicz, W. (red.). (2000). Katedra Statystyki Akademii Ekonomicznej we Wroctawiu 1950-2000. Wrocław: Akademia Ekonomiczna. 